\title{
ANALISA KINERJA KEUANGAN METODE EVA DAN MVA PADA PERUSAHAAN PT WASKITA KARYA (PERSERO) TBK TAHUN 2017- 2019
}

\author{
Muhammad Rizal Utomo ${ }^{1}$, Mutia Aprilianti Nur Azizah ${ }^{2}$, Mutiara Rahmi Fadillah ${ }^{3}$, Nadila \\ Sholehah $^{4}$, Nadyya Putri Marthiana ${ }^{5}$, Nazela Suci Akbari ${ }^{6}$, Neneng Badriah ${ }^{7}$ Setya \\ Mulyawan $^{8}$ \\ 1,2,3,4,5,6,7,8 Universitas Islam Negeri Sunan Gunung Djati Bandung \\ Email : muhamadizal10@gmail.com
}

\begin{abstract}
Abstrak
EVA dan MVA adalah salah satu metode perhitungan yang mengukur kinerja keuangan sebuah perusahaan untuk menentukan value added yang digunakan oleh investor sebagai salah satu pedoman investasi di pasar modal. Manfaatnya agar para investor mampu mengetahui apakah nilai investasinya dapat dikatakan baik atau tidak menurut kinerja keuangan perusahaan terkait. Penelitian ini bertujuan untuk menghitung nilai kinerja keuangan PT Waskita Karya pada periode 2017 sampai 2019 yang datanya diambil melalui laporan keuangan yang telah disebar luaskan oleh perusahaan sebagai bentuk transparansi. Penelitian kinerja keuangan ini berpacu pada hasil kriteria yang dilakukan pada metode EVA dan MVA yaitu ketika EVA/MVA > 0 maka nilai kinerja keuangan dapat dikatakan baik dan terdapat nilai tambah ekonomis dari perusahaan tersebut dan sebaliknya.
\end{abstract}

Kata kunci : Kinerja Keuangan, Laporan Keuangan

\begin{abstract}
EVA and MVA is one of the calculation methods that measures a company's financial performance to determine the value added used by investors as one of the guidelines for investing in the capital market. The benefit is that investors are able to know whether the investment value can be said to be good or not according to the financial performance of the company concerned. This study aims to calculate the value of the financial performance of PT Waskita Karya in the period 2017 to 2019 whose data is taken through financial statements that have been disseminated by the company as a form of transparency. This financial performance research is based on the results of the criteria conducted on the EVA and MVA method, namely when EVA/MVA>0, the value of financial performance can be said to be good and there is economic added value from the company.
\end{abstract}

Keyword : Financial Performance, Financial Statement

\section{A. PENDAHULUAN}

Sejak dahulu investasi merupakan hal wajib yang dilakukan bagi banyak orang, karena dengan berinvestasi pemilik dana dapat mempersiapkan keadaan di masa depan yang diliputi ketidakpastian. Terdapat berbagai pilihan untuk diinvestasikan dari emas, surat 
berharga, obligasi, saham, reksadana, dan lain - lain. Pihak yang memiliki kelebihan dana dan berniat untuk menyumbangkan dananya dengan harapan akan mendatangkan kemakmuran dalam investasi dapat disebut sebagai investor. Saat ini banyak investor yang terpikat berinvestasi dalam saham yang dianggap mudah dipilih dan dipilah perusahaan apa yang akan di berikan dana serta mendatangkan keuntungan yang sebanding dengan resiko yang akan dihadapi. Namun tidak dapat dipungkiri berinvestasi saham lebih mendatangkan resiko yang besar dibandingkan bunga yang kecil yang didapatkan dari menabung. Meskipun hal tersebut diketahui oleh pemilik kelebihan dana tetapi saham tetap menjadi salah satu incaran utama investor untuk menanamkan modalnya.

Pasar modal dengan perkembangannya yang pesat merupakan pilihan yang tepat untuk merealisasikan hal tersebut. Secara garis besar pasar modal atau bursa efek Indonesia merupakan tempat diperjualbelikannya instrument keuangan jangka panjang yang mempertemukan pihak yang memiliki kelebihan dana dan pihak yang membutuhkan dana dengan kegiatan perdagangan efek baik pemerintah atau swasta. Pasar modal memiliki daya pikat tersendiri dalam menarik investor. Keuntungan yang dihadapi dalam berinvestasi di pasar modal dapat mendatangkan respon positif maupun negatif. Pasar modal sebagai tempat kegiatan berinvestasi terbesar yang dilakukan baik institusi publik, lembaga maupun masyarakat. Bursa efek memiliki peranan besar kaitannya dengan perputaran kegiatan ekonomi Negara Indonesia.

Saham sebagai salah satu primadona yang diperjualbelikan dalam bursa efek merupakan bukti kepemilikan yang dimiliki seorang investor sebagai tanda bahwa ia telah menanamkan dananya pada perusahaan tersebut dan berhak atas keuntungan yang telah di peroleh. Tak sembarang perusahaan dapat dipilih, perlu pertimbangan yang saksama untuk menemukan saham mana yang akan kita tanami modal. Semakin besar resiko berpotensi mendatangkan keuntungan yang lebih pula.

Perusahaan adalah pihak utama dalam instrumen investasi yang paling bertanggung jawab untuk memberikan benefit atau keuntungan bagi para investornya, bahkan perusahaan harusnya banyak memantaskan diri supaya investor dapat tertarik berinvestasi di perusahaannya.

Penilaian kinerja sangat diperlukan bagi perusahaan untuk megetahui sejauh mana perusahaan dapat mencapai tujuan. Kinerja perusahaan merupakan tingkat keberhasilan manajemen dalam mengelola sumberdaya keuangan perusahaan, hal ini lebih difokuskan pada pengelolaan investasi perusahaan sebagai upaya untuk menciptakan nilai bagi pemegang saham atau investor. Seorang investor memerlukan penilaian kinerja sebaga infomasi dan 
investasi, sedangkan seorang manajer perusahaan memerlukan penilaian kinerja digunakan sebagai dasar untuk mengevaluasi kinerja perusahaan dan sebagai alat pertanggung jawaban kepada pemilik perusahaan atas kepercayaan yang telah diberikan untuk mengelola sumberdaya.

Menurut (Sari, 2002) dalam (NAPITUPULU, 2011) EVA atau Economic Value Added merupakan sistem penilaian atau alat ukur dari Value Based Management (VBM) atau sistem nilai tambah yang paling dikenal dan banyak digunakan untuk mengukur kinerja keuangan perusahaan. EVA sendiri merupakan suatu alat analisis dari Stern Steward \& Co dari New York, Amerika untuk perusahaannya. Apabila perusahaan dapat menutup biaya operasional dan biaya modal dapat dipastikan kesejahteraan Stakeholder pun terjamin.

EVA dapat diartikan sebagai sebuah alat analisis yang sangat berkaitan dengan saham menurut AT \& T, dibandingkan dengan alat ukur tradisional lainnya ia sangat bersinggungan dengan harga saham dikarenakan para investor menilai bahwa adanya pengembalian hasil yang penuh dari modal yang diberikan dan dinilai mampu menghasilkan return dengan perhitungan secara adil. Pernyataan diatas mengenai EVA dapat membantu manajer dan investor dalam kaitannya dengan return saham (Brigman dan Houston,1999:52) dalam (Ishak, 2009).

Demi memberikan kepastian perusahaan yang akan didanai kita perlu mengukur kinerja keuangan perusahaan tersebut dengan beberapa penilaian dari informasi keuangan. Melihat struktural perusahaan akan menambah nilai apakah dimasa mendatang perusahaan tersebut akan mengalami penurunan atau akan menimbulkan keuntungan. Patut bagi investor memprediksi laporan keuangan dan sistem melalui kinerja perusahaannya sebagai jaminan akan kesejahteraan pemegang saham di periode yang akan datang Pradhono \& Christiawan (2004) dalam (Marsiwi, 2016).

Brigham dan Houston, (2001:32) dalam jurnal Ajiwanto (2013) Dahulu perusahaan berlomba - lomba untuk memaksimalkan laba dan tidak memperhatikan kesejahteraan stakeholder, namun semakin perkembangan zaman pelaku bisnis menyadari jika mencapai keuntungan lebih bukan hal tunggal untuk merubah persepsi nilai perusahaan di hal layak tetapi ada hal lain yang perlu dimaksimalkan manajemen perusahaan diantaranya mensejahterakan pemegang saham agar mau mendanai perusahaan.

\section{EVA}

\begin{tabular}{|l|l|}
\hline Elemen EVA & Rumus Perhitungan EVA \\
\hline
\end{tabular}




\begin{tabular}{|c|c|}
\hline NOPAT & EBIT - Cash Operating Tax \\
\hline IC & $\begin{array}{c}\text { Total Liabilities \& Equity }- \\
\text { Current Liabilities }\end{array}$ \\
\hline WACC & $\{($ D $\times$ rd $)(1-T a x)+($ E $\times$ re $)\}$ \\
\hline CC & WACC $\times$ IC \\
\hline EVA & NOPAT - CC \\
\hline
\end{tabular}

Keterangan :

$\begin{array}{ll}\text { NOPAT } & : \text { Net Operating Profit After Tax } \\ \text { EBIT } & : \text { Earning Before Interest and Tax } \\ \text { IC } & : \text { Invested Capital } \\ \text { CC } & : \text { Capital Charge } \\ \text { WACC } & : \text { Weighted Average Cost of Capital } \\ \text { D (tingkat modal) } & : \text { Total utang terhadap total capital employed (\%) } \\ \text { rd } & : \text { Cost Of Debt (Beban bunga / Total utang) } \\ \text { E (tingkat ekuitas) } & : \text { Modal saham terhadap total capital employed }(\%) \\ \text { re } & : \text { Cost Of Equity (1/PER) }\end{array}$

Selain metode EVA, terdapat pendekatan lain yang dapat digunakan untuk mengukur kinerja perusahaan didasarkan pada nilai pasar yang dikenal dengan metode Market Value Added (MVA). MVA. Konsep MVA pada dasarnyaa digunakan untuk mengukur kinerja manajemen dalam mengelola perusahaan. Nilai buku ekuitas dimiliki setiap perusahaan yang tercantum dalam laporan keuangan, selain itu nilai pasar yang tercermin dimiliki setiap perusahan pada harga saham perusahaan yang tercantum dalam periode akhir selama tahun. Dengan menggunakan metode MVA dapat mengukur sejauh mana kinerja suatu perusahaan dalam mengelola dan menghasilkan nilai bagi suatu perusahaan. MVA saat ini dianggap menjadi panduan terbaik untuk menilai manajemen perusahaan publick apakah bagus atau tidaknya. 
MVA merupakan perbedaan antara nilai pasa perusahaan dan modal keseluruhan yang diinvestasikan perusahaan. MVA dapat dihitung dengan menggunakan rumus:

MVA = Nilai Perusahaan - Modal yang

Diinvestasika (IC)

\section{B. LANDASAN TEORI}

Dalam Keputusan Menteri Keuangan Republik Indonesia No. 740/ KMK.00/1989 tentang Peningkatan Efisiensi dan Produktivitas Badan Usaha Milik Negara "Kinerja keuangan merupakan sebuah reward yang telah dicapai perusahaan pada periode tertentu yang akan menjadi representasi tingkat kesehatan serta nilai perusahaan terkait. Kinerja keuangan merupakan dasar penilaian mengenai kondisi keuangan yang dapat dilakukan melalui perhitungan rasio keuangan" dalam (Sunardi, 2018)

Pasar modal merupakan tempat yang memperjualbelikan instrument keuangan jangka panjang dalam berbagai bentuk baik surat berharga atau bukti kepemilikan yang terdapat kepemilikan hak serta diharapkan mampu memberikan investor dan pihak yang membutuhkan dana mendapatkan keuntungan dengan tidak melupakan hasil resiko yang berbeda - beda baik resiko positif maupun negatif. Perdagangan saham di bursa efek terdapat berbagai jenis instrumen keuangan khususnya saham yang paling banyak diminati dan digunakan sebagai sumber investasi bagi para investor untuk menanamkan modalnya tidak hanya saham banyak preferensi lainnya yang dapat dinikmati dan dipilih sesuai dengan keinginan investor. Dengan adanya pasar modal investor dapat bergerak dengan aman tanpa memiliki rasa cemas akan disalahgunakan oleh pihak perusahaan. Namun pasar modal merupakan tipe pasar yang memunculkan ketidakpastian di masa yang akan datang. Dengan harapan investor atau pihak lainnya yang menanamkan dana di perusahaan yang terdaftar dipasar modal ialah untuk mendapatkan hasil timbal balik dari investasi yang telah dikeluarkan dan dapat memakmurkan pemegang saham itu sendiri dalam (NAPITUPULU, 2011).

EVA dikatakan dapat memperkaya pemegang saham apabila NOPAT dapat melebihi biaya modal dengan otomatis mendatangkan keuntungan. Jika EVA tinggi maka akan semakin baik nilai harga saham. Selaras dengan penelitian Ishaq (2009) jika variabel EVA memiliki pengaruh yang positif dan signifikan terhadap return saham. Berbanding terbalik dengan penelitian Methasari (2017) yang menghasilkan EVA negatif. MVA disebut sebagai perbedaan selisih nilai harga saham dengan nilai buku ekuitas. Dimana jika MVA tinggi maka akan menambah kemakmuran stakeholder. Seperti dalam jurnal Alexander \& Destriana 
(2013) bahwa MVA berpengaruh terhadap return saham dan tidak sejalan dengan penelitian Tudje (2016) yang mengahasilkan MVA berpengaruh negatif terhadap return saham.

Menurut (Nasser, 2003) dalam (Trisnawati, 2009) MVA merupakan perbedaan nilai pasar saham dengan nilai buku ekuitas dengan hasil yang tinggi maka akan mencerminkan kemampuan perusahaan dalam mensejahterakan kemakmuran para pemegang saham. Jika hasil yang didapatkan makin menurun maka dapat dipastikan penilaian pemegang saham kepada perusahaan semakin buruk. Manajemen harus memfokuskan kepada informasi yang dapat disampaikan ke pasar modal untuk merubah dan posisi nilai saham pada level teratas.

Menurut Winarto (2005:5) dikatakan bahwa menunjukkan kinerja pasar dari suatu perusahaan dengem melihat dari kemampuan perusahaan atas pengelolaan modal dari investas yang dihargai pada pasar saham. Jika pasar dapat menghargai perusahaan melibeihi tingkat modal yang diinvestasikan, makan manajemen perusahaan dikatakan mampu menghasilkan nilai bagi pemegang sahamnya. Semakin tinggi nilai MVA,maka semakin tinggi nilai tambah yang dihasilkan begitupun sebaliknya, jika nilai MVA rendah dikatakan pihak manajemen perusahaan dianggap tidak mampu menghasilkan mengasilkan nilai bagi pemegang saham.

\section{METODE PENELITIAN}

Kami melakukan analisa pada perusahaan PT Waskita Karya (Persero) Tbk melalui sajian laporan keuangan pada periode 2017-2018. Penelitian yang diarahkan pada waktu dan pembahasan tertentu membuat penelitian ini akan berjalan sesuai koridor dan fokus pada tujuannya. Kami mendaptkan informasi laporan keuangan melalui laman resmi perusahaan yang menyajikan laporan tahunan dari tahun ke tahun sebagai bentuk transparansi dan perwujudan BUMN milik masyarakat.

Data yang kami ambil adalah data sekunder yang berasal dari laporan keuangan perusahaan yang telah disebar luaskan. Lalu pada penelitian ini menggunakan metode dokumentasi dan studi pustaka sebagai metode pengumpulan data. Metode Dokumentasi adalah Metode pengumpulan data yang didapat dari dokumen - dokumen yang tersimpan, baik berupa catatan, buku, koran, majalah, internet dan lainnya.

\section{HASIL PENELITIAN}

\section{Menghitung Net Operating After Tax (NOPAT)}

\begin{tabular}{|l|l|l|l|}
\hline TAHUN & LABA SEBELUM & BEBAN & NOPAT \\
\hline
\end{tabular}


ARTIKEL

\begin{tabular}{|c|c|c|c|}
\hline & PAJAK & PAJAK & \\
\hline $\mathbf{2 0 1 7}$ & 4.620 .646 .154 .705 & 419.073 .663 .951 & 4.201 .572 .490 .754 \\
\hline $\mathbf{2 0 1 8}$ & 5.536 .442 .504 .008 & 916.874 .798 .455 & 4.619 .567 .705 .553 \\
\hline $\mathbf{2 0 1 9}$ & 1.328 .649 .961 .839 & 299.751 .593 .948 & 1.028 .898 .367 .891 \\
\hline
\end{tabular}

2. Menghitung Invested Capital

\begin{tabular}{|c|c|c|c|}
\hline TAHUN & $\begin{array}{c}\text { TOTÁ } \\
\text { DAN HUTANG }\end{array}$ & $\begin{array}{c}\text { HUTANG JANGKA } \\
\text { PENAS }\end{array}$ & $\begin{array}{c}\text { INVESTED } \\
\text { CAPITAL }\end{array}$ \\
\hline $\mathbf{2 0 1 7}$ & 97.895 .760 .838 .624 & 52.309 .197 .858 .063 & 45.586 .562 .980 .561 \\
\hline $\mathbf{2 0 1 8}$ & 124.391 .581 .623 .636 & 56.799 .725 .099 .343 & 67.591 .856 .524 .293 \\
\hline $\mathbf{2 0 1 9}$ & 122.589 .259 .350 .571 & 45.023 .495 .139 .583 & 77.565 .764 .210 .988 \\
\hline
\end{tabular}

3. Menghitung Weighted Average Cost of Capital (WACC)

\begin{tabular}{|c|c|c|c|c|c|c|}
\hline TAHUN & $\begin{array}{c}\text { TINGKAT } \\
\text { MODAL } \\
(\boldsymbol{\%})\end{array}$ & $\begin{array}{c}\text { BIAYA } \\
\text { HUTANG }\end{array}$ & TAX & EKUITAS & $\begin{array}{c}\text { BIAYA } \\
\text { MODAL }\end{array}$ & WACC \\
\hline $\mathbf{2 0 1 7}$ & $76,76 \%$ & $0,22 \%$ & $9,1 \%$ & $23,2 \%$ & $18,5 \%$ & $4,4 \%$ \\
\hline $\mathbf{2 0 1 8}$ & $76,78 \%$ & $0,27 \%$ & $16,6 \%$ & $23,2 \%$ & $16,0 \%$ & $3,9 \%$ \\
\hline $\mathbf{2 0 1 9}$ & $76,25 \%$ & $0,33 \%$ & $22,5 \%$ & $23,8 \%$ & $3,5 \%$ & $1,0 \%$ \\
& & & & & & \\
\hline
\end{tabular}

a. Tingkat Modal (D)

\begin{tabular}{|c|c|c|c|c|}
\hline TAHUN & TOTAL HUTANG & $\begin{array}{c}\text { TOTAL HUTANG } \\
\text { DAN EKUITAS }\end{array}$ & $\boldsymbol{\%}$ & $\begin{array}{c}\text { TINGKAT } \\
\text { MODAL (D) }\end{array}$ \\
\hline $\mathbf{2 0 1 7}$ & 75.140 .936 .029 .129 & 97.895 .760 .838 .624 & 100 & 76,76 \\
\hline $\mathbf{2 0 1 8}$ & 95.504 .462 .872 .769 & 124.391 .581 .623 .636 & 100 & 76,78 \\
\hline $\mathbf{2 0 1 9}$ & 93.470 .790 .161 .572 & 122.589 .259 .350 .571 & 100 & 76,25 \\
\hline
\end{tabular}

b. Biaya Hutang 
ARTIKEL

\begin{tabular}{|c|c|c|c|c|}
\hline TAHUN & BEBAN BUNGA & TOTAL HUTANG & \% & BIAYA HUTANG (Rd) \\
\hline $\mathbf{2 0 1 7}$ & 168.809 .940 .796 & 75.140 .936 .029 .129 & 100 & 0,22466 \\
\hline $\mathbf{2 0 1 8}$ & 255.818 .229 .798 & 95.504 .462 .872 .769 & 100 & 0,26786 \\
\hline $\mathbf{2 0 1 9}$ & 305.037 .581 .975 & 93.470 .790 .161 .572 & 100 & 0,32635 \\
\hline
\end{tabular}

c. Pajak

\begin{tabular}{|c|c|c|c|c|}
\hline TAHUN & $\begin{array}{c}\text { BEBAN } \\
\text { PAJAK }\end{array}$ & $\begin{array}{c}\text { LABA BERSIH SEBELUM } \\
\text { PAJAK }\end{array}$ & \% & PAJAK \\
\hline $\mathbf{2 0 1 7}$ & 419.073 .663 .951 & 4.620 .646 .154 .705 & 100 & 9,070 \\
\hline $\mathbf{2 0 1 8}$ & 916.874 .798 .455 & 5.536 .442 .504 .008 & 100 & 16,561 \\
\hline $\mathbf{2 0 1 9}$ & 299.751 .593 .948 & 1.328 .649 .961 .839 & 100 & 22,561 \\
\hline
\end{tabular}

d. Ekuitas

\begin{tabular}{|c|c|c|c|c|}
\hline TAHUN & TOTAL EKUITAS & $\begin{array}{c}\text { TOTAL HUTANG } \\
\text { DAN EKUITAS }\end{array}$ & \% & EKUITAS (E) \\
\hline $\mathbf{2 0 1 7}$ & 22.754 .824 .809 .495 & 97.895 .760 .838 .624 & 100 & 23,24393 \\
\hline $\mathbf{2 0 1 8}$ & 28.887 .118 .750 .867 & 124.391 .581 .623 .636 & 100 & 23,22273 \\
\hline $\mathbf{2 0 1 9}$ & 29.118 .469 .188 .999 & 122.589 .259 .350 .571 & 100 & 23,75287 \\
\hline
\end{tabular}

e. Biaya Modal

\begin{tabular}{|c|r|r|r|}
\hline TAHUN & WACC & INVESTED CAPITAL & \multicolumn{1}{c|}{ CAPITAL CHARGE } \\
\hline $\mathbf{2 0 1 7}$ & $4,4 \%$ & 45.586 .562 .980 .561 & 2.005 .808 .771 .145 \\
\hline $\mathbf{2 0 1 8}$ & $3,9 \%$ & 67.591 .856 .524 .293 & 2.636 .082 .404 .447 \\
\hline $\mathbf{2 0 1 9}$ & $1,0 \%$ & 77.565 .764 .210 .988 & 775.657 .642 .110 \\
\hline
\end{tabular}

f. EVA

\begin{tabular}{|c|c|r|r|}
\hline TAHUN & \multicolumn{1}{|c|}{ NOPAT } & \multicolumn{1}{c|}{ CAPITAL CHARGE } & \multicolumn{1}{c|}{ EVA } \\
\hline $\mathbf{2 0 1 7}$ & 4.201 .572 .490 .754 & 2.005 .808 .771 .145 & 2.195 .763 .719 .609 \\
\hline $\mathbf{2 0 1 8}$ & 4.619 .567 .705 .553 & 2.636 .082 .404 .447 & 1.983 .485 .301 .106 \\
\hline $\mathbf{2 0 1 9}$ & 1.028 .898 .367 .891 & 775.657 .642 .110 & 253.240 .725 .781 \\
\hline
\end{tabular}


ARTIKEL

\section{Menghitung Nilai Perusahaan}

\begin{tabular}{|c|l|l|l|}
\hline Tahun & $\begin{array}{l}\text { Jumlah Saham } \\
\text { yang beredar }\end{array}$ & Harga Saham & Nilai Perusahaan \\
\hline $\mathbf{2 0 1 7}$ & 13.573 .902 .600 & 2.210 & $\mathbf{2 9 . 9 9 8 . 3 2 4 . 7 4 6 . 0 0 0}$ \\
\hline $\mathbf{2 0 1 8}$ & 13.573 .951 .000 & 1.680 & $\mathbf{2 2 . 8 0 4 . 2 3 7 . 6 8 0 . 0 0 0}$ \\
\hline $\mathbf{2 0 1 9}$ & 13.573 .951 .000 & 1.485 & $\mathbf{2 0 . 1 5 7 . 1 4 1 . 3 3 6 . 7 5 0}$ \\
\hline
\end{tabular}

2. Modal yang DIinvestasikan (Invested Capital)

\begin{tabular}{|c|c|c|c|}
\hline TAHUN & $\begin{array}{c}\text { TOTAL HUTANG } \\
\text { DAN EKUITAS }\end{array}$ & $\begin{array}{c}\text { HUTANG JANGKA } \\
\text { PENDEK }\end{array}$ & $\begin{array}{c}\text { INVESTED } \\
\text { CAPITAL }\end{array}$ \\
\hline $\mathbf{2 0 1 7}$ & 97.895 .760 .838 .624 & 52.309 .197 .858 .063 & 45.586 .562 .980 .561 \\
\hline $\mathbf{2 0 1 8}$ & 124.391 .581 .623 .636 & 56.799 .725 .099 .343 & 67.591 .856 .524 .293 \\
\hline $\mathbf{2 0 1 9}$ & 122.589 .259 .350 .571 & 45.023 .495 .139 .583 & 77.565 .764 .210 .988 \\
\hline
\end{tabular}

3. MVA

\begin{tabular}{|c|c|c|l|}
\hline Tahun & Nilai Perusahaan & $\begin{array}{c}\text { Modal yang } \\
\text { diinvestasikan }\end{array}$ & MVA \\
\hline 2017 & 29.998 .324 .746 .000 & 45.586 .562 .980 .561 & -15.558 .238 .234 .561 \\
\hline 2018 & 22.804 .237 .680 .000 & 67.591 .856 .524 .293 & -45.311 .432 .756 .293 \\
\hline 2019 & 20.157 .141 .336 .750 & 77.565 .764 .210 .988 & $-\mathbf{5 7 . 4 0 8 . 6 2 2 . 8 7 4 . 2 3 8}$ \\
\hline
\end{tabular}

\section{E. Kesimpulan}

Kinerja Keuangan merupakan hasil simpulan dari posisi nilai perusahaan yang memiliki standar khusus, serta kriteria yang telah di tetapkan. Sawir (Adiguna, 2017 : 435) dalam (Hefrizal, 2018). Maka metode EVA akan banyak menggambarkan posisi atau nilai perusahaan yang akan dijadikan rujukan investasi bagi para investor

Dari perhitungan yang telah diselesaikan akan diperoleh kesimpulan dengan pernyataan seperti berikut : 
- Jika EVA > 0 maka hal ini merupakan interpretasi nilai tambah ekonomis yang baik bagi perusahaan

- Jika EVA < 0 maka hal ini menunjukan tidak adanya nilai tambah bagi perusahaan,

- Jika EVA = 0 maka hal ini menunjukan titik balik "impas" dari perusahaan dimana laba digunakan untuk membayar kewajiban

Hasil analisis yang dilakukan pada PT Waskita Karya (Persero) Tbk menunjukan hasil diatas kriteria dimana jika EVA > 0 maka kinerja keuangan dikatakan baik. Walaupun pada perhitungan menunjukan hasil yang sangat fluktuatif terlebih pada laba yang dihasilkan dan menunjukan adanya penurunan yang signifikan akan tetapi masih diatas kriteria penilaian EVA.

Sama hal seperti EVA, MVA memiliki indicator yangdapat disumpulkan digunakan untuk mengukur yaitu:

- Jika Market Value Added (MVA) > 0, maka bernilai positif, menunjukkan perusahaan berhasil meningkatkan nilai modal yang telah diinvestasikan.

- Jika Market Value Added (MVA) < 0, maka bernilai negative, menunjukkan perusahaan tidak berhasil meningktakan nilai modal yang telah diinvestasikan.

- Jika Market Value Added (MVA) = 0, maka pada posisi ini perusahaan dalam titik impas. Perusahaan tindak sedang mengalami kmunduran tetapi sekaligus tidak mengalami kemajuan secara ekonomi.

Beberapa kesimpulan yang bisa diambil dalam penelitian tersebut.

1. Hasil analisis kinerja keuangan perusahaan Pt Waskita Karya menunjukan hasil yang baik dan positif dimana nilai EVA masih diatas dari standar yang berlaku.

2. Walaupun laba perusahaan mengalami fluktuatif dari tahun ketahun namun hasil dari analisa EVA tetap menunjukan sisi positif.

3. Hasil pehitungan menggunakan metode MVA pada Pt. Waskita Karya (Persero) Tbk. Menunjukkan hasil yang tidak baik selama 3 tahun terakhir.

4. Nilai MVA menunjukkan nilai negative yaitu tahun 2017 - 2019. Pada tahun 2017 sebesar - 15.558.238.234.561, dan pada tahun 2018 sebesar - 45.311.32.756.293. artinya nilai pasar PT. Waskita Karya lebih kecil disbanding modal yang diinvestasikan sehingga perusahaan mampu menciptakan nilai, kinerja keuangan perusahaan dikatakan kurang baik karena MVA negative (>0) diartikan bahwa perusahaan tidak berhasil meningkatkan nilai modal yang telah diinvestasikan oleh 
penyandang dana (investor).

\section{DAFTAR PUSTAKA}

Hefrizal, m. (2018). Analisis metode economic value added untuk menilai kinerja keuangan pada pt. Unilever indonesia. 4(1), 64-73.

Marsiwi, d. (2016). Pengaruh cash value added dan earning share ratio terhadap return saham. Ekuilibrium : jurnal ilmiah bidang ilmu ekonomi, 8(1), 48.

https://doi.org/10.24269/ekuilibrium.v8i1.34

Napitupulu, e. N. (2011). Hubungan price-earning ratio (per) dan cash value added (cva) terhadap return saham (studi empiris perusahaan manufaktur yang terdaftar di bursa efek indonesia tahun 2008-2009). 1-146.

Sunardi, n. (2018). Analisis economic value added ( eva ), financial value added ( fva) dan market value added ( mva) dengan time series approach sebagai alat penilaian kinerja keuangan ( studi pada industri konstruksi ( bumn ) di indonesia yang listing di bei. 2(1), $62-76$.

Trisnawati, i. T. A. (2009). Pengaruh economic value added, arus kas operasi, residual income, earnigns, operating leverage dan market value added terhadap return saham. Jurnal bisnis dan akuntansi, 11(1), 65-78.

Maheni ika sari, bayu wijayantini. (2018). Mengukur kinerja keuangan dengan eva dan mva. Benefit jurnal manajemen dan bisnis. Vol 3 (1): 70

Novita tri buana. (2019). Analisis perbandingan pengukuran kinerja keuangan perusahaan menggunakan metode economic value added (eva) dan market value added (mva) pada perusahaan pt. Waskita karya (persero) tbk. Surakarta: universitas muhammadiyah surakarta 